\title{
Analysis Marketing Strategies Efforts to Increase Quantity Patients on Sumberglagah Hospital Mojokerto
}

\author{
Siti Kumaiyah ${ }^{1}$, Byba Melda \\ Suhita $^{2}$, Sentot Imam² \\ ${ }^{1}$ Magister of Health Study \\ Program of Institut Ilmu Kesehatan \\ STRADA Indonesia \\ ${ }^{2}$ Lecturer of Institut Ilmu \\ Kesehatan STRADA Indonesia \\ Email: \\ siti.kumaiyah67@gmail.com
}

Received : October 12, 2019

Accepted : February 13, 2020

Published : May 10, 2020

\begin{abstract}
This study aims to analyze the application of marketing strategies that have been carried out to increase the number of patients in Sumberglagah General Hospital Mojokerto. The research design used qualitative. The social situation was all the structural teams of Sumberglagah Hospital in Mojokerto. The sampling technique used Purposive sampling with the number of informants 7 people. Triangulation was carried out on 3 speakers. The research instrument was the researcher himself and the indeep interview and FGD guidelines. Data analysis uses data reduction, data presentation, data verification and data validity test. The results of the study showed that in general Sumberglagah Hospital Mojokerto in compiling a marketing plan followed the pattern and strategy of the marketing process aimed at improving quality and complete health services. The implementation of the Marketing Strategy includes types of public services with excellent services for modern leprosy care and reconstructive surgery and prosthetic services. Quantity increases occur during general patient visits. Hospital BOR has increased in general patient visits in the last 3 years. In 2016 the BOR of general patients was 67\%, 2017 was $67.5 \%$ and in 2018 was $71 \%$. While BOR for leprosy patients decreased, in 2016 amounting to $53.8 \%$ in 2017 amounting to $40.8 \%$ and in 2018 amounting to $38.08 \%$. The increase in the number of general patients does not go hand in hand with leprosy patients. The number of leprosy patient visits actually decreased. Influence factors due to the number of leprosy, the increase in trained personnel and the stigma of the community towards leprosy. The hospital's efforts to further improve and design the promotion of health services and to innovate regarding empowering health workers that are owned related to efforts to increase the quantity of patients both non-leprosy and leprosy. Especially for leprosy cases, the mobile unit program is intensified so that privacy of leprosy clients is more accommodated.
\end{abstract}

Keywords: Strategy, marketing, hospital, quantity 


\section{INTRODUCTION}

The growth of hospitals in Indonesia is increasing rapidly. The rapid growth of hospitals has led to increasingly intense competition in the field of health services (Haryanto, 2009). The community is increasingly selective in choosing the best hospital. This causes the need for hospitals to implement marketing strategies that can attract patients as desired (Budi Poniman, 2017). The marketing strategy by the hospital can be done by creating attractive advertisements, offering complete health services and approaching the community to provide information about new services. The approach to the community does not only provide information about services, but the hospital establishes good relations with the community (relationship marketing) with the aim of attracting prospective patients and maintaining the loyalty of old patients (Lau \& Ahmad, 2015).

Relationship marketing is an effort to approach companies to attract and retain customers through fostering relationships with their customers (Lupiyoadi, 2008). Hospitals that use Relationship marketing are believed to make patients more satisfied (Julia, 2013). The relationship marketing strategy that is implemented, besides making patients feel satisfied can also create patient loyalty. Patients who are loyal will increase the number of patient visits. Tjiptono (2010) states that customer commitment to service is based on a very positive attitude and is reflected in repeated and consistent reuse. And impact on increasing the number of patients visiting hospitals.

Sumberglagah General Hospital is one of the many hospitals in Mojokerto district that provide health services for the community. Sumberglagah General Hospital is a government hospital under the direct control of the East Java provincial government which has business competitors in the form of hospitals, private hospitals and 24-hour clinics, medical centers, alternative medicine. This competitive condition requires the hospital management to be sensitive to the needs of the community, technological changes and environmental developments that occur and make continuous improvements in providing satisfactory services to patients that have an impact on increasing the quantity of patient visits.

Management of Sumberglagah Hospital has made changes and improvements to its performance, especially in terms of services that are always oriented to patient satisfaction. The efforts that have been made are satisfaction assessments through questionnaires, message books, suggestion boxes, building partnerships and collaborating with patients (seeking communication with patient, fine). The manager gives authority to employees to provide services that satisfy patients and carry out continuous and continuous quality improvements to create and support a relationship marketing strategy (strategy relationship marketing).

Needs and demands of the community for quality health services have made Sumberglagah Hospital in recent years improve the quality of services by implementing marketing such as facilitating employees, especially medical personnel and paramedics to quickly respond to patient complaints, apply $3 \mathrm{~S}$ (smile, greetings and greetings). This marketing implementation makes the number of patients increase. Increasing the number of patients is one indicator of the success of hospital marketing strategies. In 2015 Sumberglagah Hospital had 4331 patients, in 2016 had 4104 patients, and in 2017 had 4224 patients. The next interview was conducted for patients admitted to the inpatient room stating that they knew the existence of the Sumberglagah General Hospital because they were referred Pungging Health Center. The patient was first admitted to the hospital. Previously the patients did not know the existence of the Sumberglagah Hospital. The Head of Administration stated that the analysis of the increase or decrease in the number of patients visiting had not yet touched the relationship of patient satisfaction with the implementation of marketing at Sumberglagah General Hospital.

Parameter of success of the relationship marketing strategy is customer satisfaction. Customer satisfaction is interpreted as a comparison between services or results received which must at least be the same as the customer's expectations or exceed them. Successful relationship marketing will give satisfaction to customers which will eventually form customer loyalty (Budi Poniman, 2017). Customer satisfaction is one measure of the performance of non-financial organizations that has a very significant contribution to the success of business organization goals. Specific benefits of customer satisfaction are said to have a positive relationship with customer loyalty, potentially increasing patient visits and becoming a source of future income (Lau \& Ahmad, 2015).

The purpose of this study was to analyze the marketing strategy as an effort to increase the quantity of patients at Sumberglagah Hospital in Mojokerto. 


\section{METHODS}

This study used a descriptive research design with a qualitative approach. The social situation of this study is all the structural teams of the Sumberglagah General Hospital in Mojokerto. Data retrieval was carried out at the date 1 to 25 November 2018. The sampling technique used by researchers purposive sampling of informants, amounting to 7 people. Triangulation is done to validate the data that has been obtained to 3 speakers. The instruments used were the researchers themselves and in-depth interview guidelines (indeep interview) and FGD (Focus Group Discussion). Data analysis uses data reduction, data presentation, data verification and data validity test. The technique used in examining the credibility of data is triangulation with sources to check the validity of the data.The study was conducted after passing the ethical test by an assessment team from Institut Ilmu Kesehatan STRADA Indonesia.

\section{RESULTS}

\section{Marketing strategy plan}

Marketing process patterns and strategies: marketing is the spearhead of hospital activities because marketing aims to increase patient visits to create maximum profits or profits.

The marketing strategy plan component includes basic and superior service products, tariff setting, building arrangement, and promotion efforts. The human resource development plan includes all hospital employees, both medical, non-medical paramedics. The budget in the strategy plan includes a budget for the development of human resources for training needs and skill enhancement in their respective fields. Stakeholder's role in determining marketing strategies by providing input on service quality and quantity.

Implementation of marketing strategies with the consideration that good marketing strategy planning is not enough to show marketing commitment, but also accompanied by implementation as planned.

The types of services at Sumberglagah Hospital include emergency department, outpatient care, inpatient care, clinical laboratory, operating room, pharmacy, nutrition, medical rehabilitation \& acupuncture, radiology, medical records, Social Sciences Hospital, laundry and prothese, leprosy services are reconstructive surgery. Determination of rates is arranged based on unit cost direct costs and indirect costs. Determination of rates especially class III must be by the Hospital Law of 2009 and according to BPJS rules as the most dominant insurance party in Sumberglagah Hospital " . Method and method of payment of BPJS patients payments are accumulated by BPJS regulation. Payment methods for general patients with cash without advances at the beginning of the marketing period.

Access to Hospital Services at Sumberglagah Hospital has advantages in facing competition with health services including easy access with visits to high care mobile units. Media marketing is carried out by hospitals that aim to increase public awareness. The media used in addition to print media with social media Facebook, WhatsApp and conventional methods such as leaflet. Hospital Service Standards are set out in a guide to carrying out the duties and functions of each element or unit in the form of an SOP for each service activity. And Sumberglagah Hospital has received ISO 2005.9001 certificate

Quantity of patient visits at Sumberglagah General Hospital Mojokerto in 2015 had in patient visits of some patients as many as 4331 patients, in 2016 had a total patient of 4104 patients, and in 2017 had a total of 4224 patients. As of November 2018, there were 5021 patients. The number of patient visits are shown in the Bed Occupation Rate (BOR) data at the Sumberglagah general hospital in Mojokerto. BOR of hospital has increased in general patient visits in the last 3 years. In 2016 the BOR of general patients was $67 \%, 2017$ was $67.5 \%$ and in 2018 was $71 \%$. While the BOR for leprosy patients decreased, in 2016 amounting to $53.8 \%$ in 2017 amounting to $40.8 \%$ and in 2018 amounting to $38.08 \%$

\section{DISCUSSION}

\section{Marketing strategy plan}

The pattern and strategy of the marketing process carried out by the hospital as a health care provider must have a clear purpose. The objective of the Sumberglagah Hospital marketing strategy is to improve quality and complete health services for patients, improve professional, accountable and transparent hospital management and improve partnership networks, coordination, education and 
research with relevant institutions in health services, will provide the right marketing strategy direction target.

Kotler and Armstrong (2008) marketing is the process of introducing, creating, maintaining and strengthening products produced by producers According to Chan (2008) marketing (marketing) is the introduction of each customer more closely with the products of the company. Tjiptono (2010) marketing is a strategy of exchange transactions between a seller and a continuing buyer does not end after the sale is completed, in other words a partnership with a customer creates repeat business. The marketing strategy applied by the company to attract consumers and maintain the number of visits. Marketing will run well if the customers have long-term needs and have a high transition or in other words relationship marketing is very tied to a particular system and expects consistent and timely service (Purnomo Budi, 2017).

The hospital marketing orientation is not only done with activities oriented to activities that provide direct financial benefits, but also in other activities in the form of social services. One stated that Sumberglagah Hospital also served services, namely those outside the hospital, such as community service, which included periodic counseling, for example.

Marketing or marketing is one of the marketing strategies undertaken by companies to attract new consumers and to retain old consumers. According to Yon Oliver, Richad L. (2009) in forming stronger bonds with customers, marketing can be done with three approaches, namely financial benefits, social benefits and components of structural ties.

Patient satisfaction is a level of feeling of the patient that arises as a result of the performance of health services obtained after the patient compares it with what he expected (Pohan, 2013). Sangadji and Sopiah (2013) as for the factors that influence patient satisfaction include assurance of knowledge, ability, politeness, and trustworthiness possessed by service providers in hospitals both doctors, nurses, pharmacists, medical rehabilitation, administrative staff and support staff others.

The ability to work displayed or known as the performance of hospital HR is a core service that has been received by patients and is very influential on perceived satisfaction. The manifestation of this performance, for example, is the speed, convenience and comfort provided by nurses and doctors. The patient's trust in Sumberglagah Hospital that the marketing strategy is superior to the quality of human resources that excel in competence and good ethics and friendliness. This belief cannot just be recognized by the patient, but must be built from the beginning and can be proven. Trust has been considered as a catalyst in various transactions between sellers and buyers so that customer satisfaction can be realized as expected (Yousafzai et al., 2013). According to Morgan and Hunt (2014) trust (trust) will occur if someone has confidence in an exchange with partners who have integrity and can be trusted. According to Hunt, S. D., \& Morgan, R. M. (2014) said that commitment is a mutual trust that is created in a relationship, which is an important component as a guarantee for a maximum effort in maintaining the relationship.

The results of data collection on the importance of stakeholder involvement with marketing strategy plans. Stakeholders relate directly to the making of policies, programs and projects. Ndubisi (2010) explains that stakeholder analysis is a systematic analysis in collecting and analyzing information qualitatively to determine whose interests need to be considered to develop or determine programs or policies. The importance of accommodating the interests of each stakeholder is to create a mutually beneficial two-way relationship and also as a basis for the overall development of the hospital. Two-way relationships and mutual benefits require effective communication. Communication is the process of interaction or mutual understanding of each other between humans. The process of interaction or relationship with each other desired by a person with the intention to be able created a mutually beneficial two-way relationship and also as the basis for the overall development of the hospital. Two-way relationships and mutual benefits require effective communication. Communication is the process of interaction or mutual understanding of each other between humans. The process of interaction or relationship with each other that is desired by a person with the intention that it can be accepted and understood among each other (Soewarno, 2010). According to Handoko (2016) Communication is the process of transferring understanding in the form of ideas or information from someone to someone else. Robbinette (in Indah et al., 2016) states that communication is a media that can help companies deliver and understand customer desires, needs, and expectations. 


\section{Implementation of the Examination Strategy}

Good marketing strategy planning is not enough to show marketing commitment, but also accompanied by implementation as planned. Azwar (2008) quality health services are health services that can satisfy every service user by the average level of satisfaction of the population and its implementation by the standards and professional code of ethics that have been set.

The type of service in the hospital includes the main activities of a hospital, namely healing in a person or a lot of people so that the person can return to carrying out their daily activities without being disturbed by abnormalities or abnormal physical or mental functions. Sumberglagah Hospital has provided standard care for type $\mathrm{C}$ hospitals according to hospital laws. RSU also provides superior services. Excellent service in the form of leprosy treatment and prosthetic orthotics.

One of the basic requirements of good health services is easy to reach. Easy to reach are interpreted from the point of cost to realize the conditions that must be sought for the cost of health services by the economic capacity of the community (Yasin, 2010). Being a BPJS and JKN participant is a right for Indonesian citizens and the government has declared that in the next few years it is expected that all Indonesian people will become participants in the National Health Insurance and Health Insurance Provider. For this reason, it is necessary and important to know the conditions for registering BPJS Health participants as government programs in the health sector (Pohan, 2013).

Supriyanto, S \& Ernawaty (2010) quality hospitals provide satisfaction to patients. Patients who have obtained a product or service, feel satisfied if they do not need to incur additional costs or do not need to waste time getting services, so they will tend to be satisfied with these services (Jones, Thomas O., and Sasser W Earl Jr., 2015). One of the things that affects satisfaction is one of conformance to specification, namely the extent to which service characteristics meet the standards set beforehand. For example, marketing about standard prices and emissions is fulfilled such as how to pay for equipment and treatment obtained during the hospital.

Griffith (2017) there are several aspects that affect feelings of satisfaction with someone, namely service and location. Sumberglagah Hospital has an advantage in facing competition with health services including the ease of accessing hospital services. The ease of access with the strategies taken depends on speed and carrying out visits to high care areas. Outpatient service products are socialized to the public through social media and print so that people are easy to know and complete with the hotline number. Various efforts were made by the Sumberglagah Hospital in Mojokerto which aimed to increase public awareness. Hospitals use more electronic media, social media and use conventional methods such as leaflet.

Standard Operating Procedure (SPO) is a set of instructions / steps that are standardized to complete a certain routine work process. The SPO provides the right and best steps to carry out various activities and functions. According to Morgan and Hunt (2014) said that commitment is a mutual trust that is created in a relationship, which is an important component as a guarantee for a maximum effort in maintaining the relationship. SOP is a form of hospital commitment to providing the best service. Sumberglagah General Hospital composes a guide for carrying out the duties and functions of each element or unit. And the guidelines are outlined in the form of SOP so that health services are guaranteed quality.

\section{Quantity of Patient Visits}

The quantity of patient visits is an indicator of the success of hospital management. Information 1 and 7 according to medical record data state the number of patient visits at the Sumberglagah General Hospital in Mojokerto increased for general patient visits and decreased leprosy patient visits. The number of patient visits is shown in the Bed Occupation Rate (BOR) data at the Sumberglagah general hospital in Mojokerto district. Hospital BOR has increased in general patient visits in the last 3 years.

The concept of patient quantity in principle is a standard number of patient visits to the hospital (Budiastuti, 2012). This is inseparable from the hospital's target of increasing the number of patients from time to time. The increase in the number of patients will go hand in hand with an increase in hospital income and impact on increasing employee welfare. Also, the hospital will be able to improve services in the form of increasing service types and patient service quality (Buttle, 2007). The concept of service quality is a quality standard that must be understood in providing actual services about 
marketing with service quality (Suryanti, E.M., dan Qomariyah, 2013). This is not only a story or something that is making it up but must be adapted to a reasonable standard, such as the ISO standard.

The standard number of patient visits to Sumberglagah general hospital is increasing. Increased quantity occurs in general patient visits. General patients not only come from within the city of Mojokerto but also referrals from areas nearby the nearest city, Pasuruan. Of course this is inseparable from the target of Sumberglagah's hospital, which is an increase in the number of patients from time to time. The increase in the number of patients will go hand in hand with an increase in hospital income and impact on increasing employee welfare. Also, the hospital will be able to improve services in the form of increasing the types of services and quality of patient services. The increase in the number of general patients does not go hand in hand with leprosy patients. The number of leprosy patient visits actually decreased. The decrease in the number of leprosy patient visits can be influenced by several factors. This factor is due to the number of leprosy, increased competence of health workers at the level 1 health facility and because of the stigma of the people who are still attached to leprosy. This can result in decreased visits by leprosy patients.

\section{CONCLUSION}

The hospital's efforts to further improve and design the promotion of health services and to innovate regarding empowering health workers that are owned related to efforts to increase the quantity of patients both non-leprosy and leprosy. Especially for leprosy cases, the mobile unit program is intensified so that privacy of leprosy clients is more accommodated. However, the increase in the number of general patients does not go hand in hand with leprosy patients. The number of leprosy patient visits actually decreased. The decrease in the number of leprosy patient visits can be influenced by several factors. These factors are partly due to the declining rate of leprosy in the community. A part from being treated by leprosy in the community, it can be handled by trained personnel at the Puskesmas; this is also due to the community's stigma that is still attached to leprosy as a disgusting and karmic disease so patients are reluctant to come to the hospital. The hospital's efforts to further improve and design health service promotions and innovate regarding empowerment.

\section{REFERENCES}

Azwar, Azrul H. 2008. Menjaga Mutu Pelayanan Kesehatan. Jakarta: Pustaka Sinar Harapan

Budiastuti, FX. (2012). Pelayanan Pelanggan yang Bermutu, Seni Melakukan Pelanggan Sebagai Тати. Jakarta: Binarupa Aksara

Buttle (2007) Theoretical Testing On Service Quality And Product Innovation Of Small-Micro Credit

Banks (A Case Study). Journal of economics, Business, \& accountancy. Ventura: center for research and community service (PPPM), Vol. 14, No. 3 pp 235-238

Chan (2008) RelationshipMarketing. Jakarta. Gramedia

Griffith, D.D. dan Stephen W. Brown. (2017) Service Loyalty: Its Nature, Important, and Implications. New York: Internasional Service Qualiy Asosiation Inc.

Haryanto (2009) Menjaga Mutu Pelayanan Kesehatan. Jakarta: Pustaka Sinar Harapan

Handoko, M.B.A.,T.Hani. (2008) Manajemen Personalia dan Sumber Daya Manusia,BPFE, Yogyakarta.

Hidayat. (2010) Pengaruh Kualitas Layanan terhadap Kepuasan Pelanggan dalam Membentuk Loyalitas Pelanggan. Jurnal Ilmu Administrasi dan Organisasi. Volume 17, Nomor 2 hlm. 114126 
Indar, Etty, (2008) Pergeseran Paradigma Pemasarn Suatu Kajian Teoritik dan Filosofi Pendukung Relationship Marketing, Jurnal Ekonomi dan Perbankan Probank Vol. 9 No. 3 Hal. 177-222

Jones, Thomas O., and Sasser W Earl Jr. (2015) why satisfied customer de fect, Harvard business review, vol.73 No. 6, PP. 88- 100

Julia (2013) Pengaruh relationship marketing terhadap loyalitas pelanggan melalui kepuasan pelanggan pada PT.TikiJalur Nugra Ekakurir (JNE) di Kota Jember. Skripsi : Universitas Jember

Kotler, Philip dan Amstrong, Gary. (2008) "Prinsip Prinsip Pemasaran (Edisi bahasa Indonesia). Edisi ketiga. Jilid I. Jakarta : PT. Prenhalindo

Lau C.C., Ahmad M.I. (2015) Employment of Relationship Marketing Strategies for Enhancing Customer Satisfaction in Malaysian Private Hospitals. In: Sidin S., Manrai A. (eds) Proceedings of the 1997 World Marketing Congress. Developments in Marketing Science: Proceedings of the Academy of Marketing Science. Springer, Cham. https://doi.org/10.1007/978-3-319-17320-7_140

Lupiyoadi, Rambat. 2011. Manajemen Pemasaran Jasa. Jakarta: PT Salemba Empat. Lupiyoadi,

Rambat. 2011. Manajemen Pemasaran Jasa. Jakarta: PT Salemba Empat.Muninjaya, Gde AA, (2013) Manajemen Mutu Pelayanan Kesehatan, Jakarta, EGC.

Hunt, S. D., \& Morgan, R. M. (2014). Relationship marketing in the era of network competition. Marketing management, 3(1), 18.

Ndubisi. (2010), Metode Penelitian Survei, Jakarta: LP3ES

Sangadji \& Sopiah (2013) Manajemen Keperawatan Aplikasi dalam Praktik Keperawatan Profesional. Jakarta: Salemba Medika

Parasuraman (2008) Delivering Quality Service. New York: The Free Press.

Pohan, Imbalo (2013) Jaminan Mutu Layanan Kesehatan : Dasar-Dasar Pengertian Dan Penerapan. Jakarta: EGC.

Poniman Budi (2017) Pengaruh Implementasi Relationship Marketing Terhadap Tingkat Kepuasan Pasien di Rumah Sakit Umum "YAKKSI" Gemolong Sragen, Bhirawa, Vol 1 no 2

Suryanti, E.M., dan Qomariyah (2013) Perilaku Konsumen: Pendekatan Praktis Disertai: Himpunan Jurnal Penelitian. Yogyakarta: Penerbit Andi.

Supriyanto, S \& Ernawaty, (2010) Pemasaran Industri Jasa Kesehatan. Yogyakarta: C.V Andi

Tjiptono, Fandy. (2010) Pemasaran jasa. Malang : Bayu Media Publishing

Yon Oliver, Richad L. (2009) Satisfaction abe haviroal prespective on the customer. New York : the MC Graw - Hill companise. Inc

Yasin (2010) Permasalahan SDM.Rumah Sakit di Era Desentralisasi, jurnal Manajemen Kesehatan Vol 3 No.2. Jakarta.

Yuosafrei. (2013) Kepemimpinan dalam Organisasi. Edisi Kelima. Jakarta: Indeks 